\title{
IMPLEMENTASI METODE ALGORITMA K-MEANS CLUSTERING PADA TOKO EIDELWEIS
}

\author{
Reno Supardi, Indra Kanedi \\ Program Studi Sistem Informasi Fakultas Ilmu Komputer Universitas Dehasen Bengkulu \\ Jl, Meranti Raya No. 32 Kota Bengkulu 38228 Telpon (0736) 22027,26975 Fax. (0736) 341139 \\ renosupardi00@gmail.com, indrakanedi12@gmail.com
}

\begin{abstract}
In making the application, the implementation of the K-Means Clustering Algorithm method at the Eidelweis Store will be designed for this study to design software at the Eidelweis Store. The method used in making this application is a system development method starting from problem determination, actual system analysis, new system analysis, system design, system implementation, and system testing. In the implementation of the K-means Clustering algorithm method on the Eidelweis Store, the login menu, input menu, output menu and report menu, and main menu. In the main menu, there is a system that is connected to the next menu in the process to view reports about sales on taking Eideleweis easy to operate The results of the implementation process of the K-means Clustering algorithm method at Eidelweis Stores have been applied to the K-means Clustering method. The application of the K-means Clustering algorithm method in Eidelweis Stores is made using Visual Basic Net programming language with the SQL Server database.
\end{abstract}

Keywords: K-means Clustering Algorithm Method, Visual Basic Net.

\begin{abstract}
Abstrak - Dalam Pembuatan Aplikasi Implementasi Metode Algoritma K-Means Clustering pada Toko Eidelweis akan dirancang tujuan penelitian ini adalah untuk membuat perancangan perangkat lunak software pada Toko Eidelweis, Metode yang gunakan pada pembuatan aplikasi ini adalah metode pengembangan sistem yang dimulai dari penentuan masalah, analisi sistem aktual, analisis sistem baru, perancangan sistem, implementasi system dan uji coba sistem. Dalam implementasi metode algoritma K-means Clustering pada Toko Eidelweis menu login, menu input, menu output dan menu laporan, menu utama. Pada menu utama terdapat sistem yang menghubungkan ke menu - menu selanjutnya dalam proses untuk melihat laporan tentang penjualan pada took Eideleweis mudah untuk dioperasikan. Hasil proses implementasi metode algoritma K-means Clustering pada Toko Eidelweis telah diterapkan metode K-means Clustering, Aplikasi implementasi metode algoritma Kmeans Clustering pada Toko Eidelweis dibuat dengan Bahasa pemrograman Visual Basic Net dengan database SQL Server.
\end{abstract}

Kata Kunci : Metode Algoritma K-means Clustering, Visual Basic Net.

\section{PENDAHULUAN}

Di Era globalisasi, perkembangan kecanggihan jaringan komunikasi yang semakin pesat merupakan aspek yang dapat dimanfaatkan untuk mencapai kemudahan. Dimana Informasi tersebut terlihat semakin marak dengan penggunaan komputer yang memang sudah sangat luas diberbagai bidang kehidupan misalnya di bidang penjualan, bisnis , usaha pada bidang bisnis yang semuanya itu menuntut penggunaan dari komputer. Penerapan Teknologi Informasi dalam dunia bisnis penjualan produk dapat menghasilkan data yang berlimpah

Peneliti sebelumnya terdahulu telah menerapakan teknik K-Means Clustering sebagai penelitian dalam hal Pengelompokkan data, diantaranya : Ediyanto [1] Dalam Penelitiannya yang berjudul "Pengklasifikasian Karakteristik Dengan Metode K-Means Cluster Analysis". Peneliti dalam penelitian ini menjelaskan bahwa metode K-Means Cluster Analysis cukup efektif diterapkan dalam proses pengklasifikasian karakteristik terhadap objek penelitian. Algoritma K-Means juga tidak terpengaruh terhadap urutan objek yang digunakan, hal ini dibuktikan ketika peneliti mencoba menentukan secara acak titik awal pusat cluster dari salah satu objek pada permulaan perhitungan.

Dari penelitian yang dilakukan oleh Ediyanto[1], oleh Ong Johan Oscar[2], serta penelitian yang dilakukan T. Gomasathit[3] disimpulkan bahwa Algoritma K-Means clustering dapat digunakan dalam mengelompokkan data dengan efisien dan efektif dengan hasil yang diharapkan. Hal inilah yang mendasari peneliti dalam melakukan penelitian dalam hal penerapaan Algoritma K-Means Clustering pada data penerimaan mahasiswa baru tahun ajaran 2014/2015 dengan studi kasus langsung ke target yang ditujuh dalam hal ini melakukan studi kasus pada Universitas Potensi Utama.

Pada penelitian ini peneliti menggunakan toko Eidelweis merupakan toko yang bergerak dalam penjualan pakaian seragam aparat keamanan seperti seragam ABRI, Kepolisian, Satpam, PNS. Dalam rangka menghadapi persaingan bisnis terdapat 
beberapa permasalahan yang kerap muncul mengenai penjualan pakaian seragam tersebut. Toko Eidelweis. Ketersediaan data penjualan yang besar toko Eidelweis idak digunakan semaksimal mungkin, sehingga data penjualan tersebut tidak dimanfaatkan secara optimal.

\section{LANDASAN TEORI}

\section{A. Pengertian metode Algoritma K-Means Clustering} K-Means Clustering merupakan suatu metode untuk mencari dan mengelompokkan data yang memiliki kemiripan karakteriktik (similarity) antara satu data dengan data yang lain. Clustering merupakan salah satu metode data mining yang bersifat tanpa arahan (unsupervised), maksudnya metode ini diterapkan tanpa adanya latihan (training) dan tanpa ada guru (teacher) serta tidak memerlukan target output. Dalam data mining ada dua jenis metode clustering yang digunakan dalam pengelompokan data, yaitu hierarchical clustering dan non-hierarchical clustering. Hierarchical clustering adalah suatu metode pengelompokan data yang dimulai dengan mengelompokkan dua atau lebih objek yang memiliki kesamaan paling dekat.

Kemudian proses diteruskan ke objek lain yang memiliki kedekatan kedua. Demikian seterusnya sehingga cluster akan membentuk semacam pohon dimana ada hierarki (tingkatan) yang jelas antar objek, dari yang paling mirip sampai yang paling tidak mirip. Secara logika semua objek pada akhirnya hanya akan membentuk sebuah cluster. Dendogram biasanya digunakan untuk membantu memperjelas proses hierarki tersebut. Berbeda de metode hierarchical clustering, metode non-hierarchical clustering justru dimulai dengan menentukan terlebih dahulu jumlah cluster yang diinginkan (dua cluster, tiga cluster, atau lain sebagainya). Kemudian jumlah cluster akan diketahui, baru proses cluster dilakukan tanpa mengikuti proses hierarki. Metode ini biasa disebut dengan K- Means Clustering[2].

K-means merupakan salah satu metode data clustering non-hirarki yang mengelompokan data dalam bentuk satu atau lebih cluster/kelompok. Datadata yang memiliki karakteristik sama dikelompokan dan data yang memiiki karakteristik yang berbeda dikelompokan dengan cluster/kelompok yang lain sehingga data yang berada dalam satu cluster/kelompok memiliki tingkat variasi yang kecil[2].

Secara umum Algoritma K-Means clustering memiliki langkah -langkah pengelompokan diantaranya adalah sebagai berikut :

1. Pilih jumlah cluster $\mathrm{k}$.

2. Dimana nilai $\mathrm{k}$ pada pusat cluster ini bisa dilakukan dengan berbagai cara. Namun yang paling sering dilakukan adalah dengan cara random. Pusat-pusat cluster diberi nilai awal dengan nilai random. Dan untuk menentukan nilai pusat cluster pada iterasi berikutnya ditentukan dengan menggunakan rumus sebagai berikut :

$$
\begin{aligned}
& =(D . i, j) \\
& \sqrt{\left(X_{1 i}-X_{1 j}\right)^{2}+\left(X_{2 i}-X_{2 j}\right)^{2}+.+\left(X_{k i}-X_{k j}\right)^{2}}
\end{aligned}
$$

\section{Dimana :}

$D(i, j)=$ jarak data ke $i$ ke pusat cluster $j$

$\mathrm{Xki}=$ data ke $\mathrm{i}$ pada atribut data ke $\mathrm{k}$

$\mathrm{Xkj}=$ titik pusat $\mathrm{ke} \mathrm{j}$ pada atribut $\mathrm{ke} \mathrm{k}$

3. Hitung pusat cluster dengan keanggotaan cluster yang sekarang. Titik data cluster adalah merupakan dari semua data dalam cluster tertentu. Jika dikehendaki bisa juga menggunakan median dari cluster tersebut. Jadi rata-rata (mean) bukan satu-satunya ukuran yang bisa dipakai.

4. Tugaskan lagi setiap objek memakai pusat cluster yang baru. Jika pusat cluster tidak berubah lagi maka proses clustering selesai. Atau kembali ke langkah nomor 3 sampai pusat cluster tidak berubah lagi.

5. Tugaskan lagi setiap objek memakai pusat cluster yang baru. Jika pusat

cluster tidak berubah lagi maka proses clustering selesai. Atau, kembali ke langkah nomor 3 sampai pusat cluster tidak berubah lagi.

Algoritma K-Means Clustering, mempunyai tahapan diantara lain adalah:

1. Menentukan jumlah cluster, jumlah cluster merupakan jumlah kelompok data yang akan dibuat atau dihasilkan.

2. Centroid awal. Centroid awal diperoleh secara acak, dan jumlah centroid sebanyak cluster yang akan dibuat. Centroid awal merupakan titik pusat cluster pertama atau awal pusat cluster.

3. Distance space data ke masing-masing centroid. Formula menghitung jarak ke masing-masing cluster.

$$
d_{\text {euclidean }}(x, y)=\sqrt{\sum_{i=1}^{n}\left(x_{i}-y_{i}\right)^{2}}
$$

Dimana :

$\mathrm{x}$ dan $\mathrm{y}$ : representasi nilai atribut dari dua record.

4. Pengelompokkan data cluster

5. Kembali ke step 3, apabila masih ada data yang berpindah cluster atau apabila ada perubahan nilai centroid, ada yang diatas nilai threshold yang ditentukan atau apabila perubahan nilai pada objective function yang digunakan dia atas nilai threshol yang ditentukan. Sedangkan formula membangkitkan centroid baru

$$
C=\frac{\sum m}{n}
$$

Dimana :

$\mathrm{c}=$ centroid data 


$$
\begin{aligned}
\mathrm{m}= & \text { anggota data yang termasuk ke dalam } \\
& \text { centroid tertentu } \\
\mathrm{n}= & \begin{array}{l}
\text { jumlah data yang menjadi anggota } \\
\text { centroid tertentu }
\end{array}
\end{aligned}
$$

Menghitung distance space ke centroid yang baru untuk iterasi berikutnya Secara matematis metode KMeans dapat menggunakan rumus sebagai berikut :

Secara matematis metode K-Means dapat menggunakan rumus sebagai berikut

$$
C=\frac{1}{M} \sum_{j=1}^{M} x_{j}
$$

Dimana :

Ci : Centroid fitur ke-i

$\mathrm{m}$ : jumlah data dalam sebuah kelompok

i : Fitur ke i dalam sebuah kelompok

$$
\left(x_{2}, x_{1}\right)=\left\|x_{2}-x_{1}\right\| \sqrt{\sum_{j=1}^{p}\left|x_{2 j}-x_{1 j}\right|^{2}}
$$

Dimana :

D : Jarak antara data X2 dan X1

|.| : Nilai Mutlak

B Data Mining

Data mining merupakan salah satu proses untuk mempekerjakan satu atau lebih teknik pembelajaran komputer (machine learning) untuk menganalisis dan mengekstraksi pengetahuan (knowledge) secara otomatis. Mining adalah suatu istilah yang digunakan untuk menguraikan penemuan pengetahuan didalam database. Data mining adalah proses[4].

\section{Penggelompokan Data Mining}

Dalam Penerapan metode data mining dapat dibagi menjadi beberapa kelompok berdasarkan tugas yang dilakukan, diantaranya adalah sebagai berikut[4] :

a. Di

Terkadang peneliti dan analisis secara sederhana ingin mencari cara untuk menggambarkan pola dan kecenderungan yang terdapat dalam data.

b. Estimasi

Estimasi hampir sama dengan klasifikasi, kecuali variable target estimasi lebih kearah numeric dari pada ke arah kategori. Model dibangun menggunakan record lengkap yang menyediakan nilai dari variable target sebagai nilai prediksi.

c. Prediksi

Beberapa metode dan teknik yang digunakan dalam klasifikasi dan estimasi dapat pula digunakan untuk keadaan yang tepat dalam $\mathrm{u}$ prediksi.

d. Klasifikasi

Dalam klasifikasi, terdapat target variable kategori. Sebagai contoh, penggolongan pendapatan dapat dipisahkan dalam tiga kategori, yaitu pendapatan tinggi, pendapatan sedang, dan pendapatan rendah.

e. Pengklusteran

Pengklusteran mrerupakan pengelompokan record pengamatan, atau memperhatikan atau membentuk kelas objek-objek yang memiliki kemiripan. Dimana kluster merupakan kumpulan record yang memiliki kemiripan suatu dengan yang lainnya dan memiliki ketidak miripan dengan record dalam kluster lain.

f. Asosiasi

Asosisasi dalam data mining adalah menentukan atribut yang muncul dalam suatu waktu. Dalam dunia bisnis lebih umum disebut analisis keranjang belanja.

\section{Tantangan Dalam Data Mining}

Ada beberapa tantangan yang terdapat pada data mining diantaranya adalah sebagai berikut :

a. Dimensionality, yaitu banyaknya jumlah atribut dalam data yang akandiproses

b. Scalability, yaitu besarnya ukuran basis data yang digunakan.

c. Data Quality, kualitas data yang akan diproses seperti data yang bersih dari noise, missing value, dsb.

d. Complex and Heterogeneous Data, yaitu data yang kompleks dan mempunyai variasi yang beragam

e. Privacy Preservation, yaitu menjaga kerahasiaan data yang banyak diterapkan pada data nasabah perbankan.

f. Streaming Data, yaitu aliran data itu sendiri

E. Tahap-tahap dalam data mining

Data mining adalah istilah yang digunakan untuk menemukan pengetahuan baru yang tersembunyi di dalam penyimpanan data yang berukuran besar. Data mining merupakan proses semi otomatis yang menggunakan teknik statistik, matematika, kecerdasan buatan, dan machine learning untuk mengekstraksi dan mengidentifikasi informasi yang bermanfaat dan pengetahuan yang terkait dari berbagai basis data yang besar.

Data mining merupakan istilah dari knowledge discovery in database yang sering kali digunakan secara bergantian unutk menjelaskan proses penggalian informasi tersembunyi dalam suatu basis data yang besar. Sebenarnya kedua istilah tersebut memiliki konsep yang berbeda,tetapi berkaitan satu sama lain. Dan salah satu tahapan dalam keseluruhan proses adalah data mining. Ada lima tahapan yang terdapat pada tahapan data mining yaitu[4]: 
a. Pre-processing / Cleaning

Proses data mining bisa dilakukan dalam proses cleaning pada data yang menjadi fokus KDD.

b. Transformation

Transformasi pada data tersebut sesuai untuk proses data mining. Proses coding dalam KDD merupakan proses kreatif dan sangat tergantung kepada jenis, atau pola informasi yang akan dicari

c. Data Selection

Data yang perlu dilakukan sebelum tahap penggalian informasi dalam KDD dimulai dari data hasil seleksi yang akan digunakan untuk proses data mining disimpan dalam suatu berkas, terpisah dari basis data operasional.

d. Data Mining

Data mining amerupakan proses untuk mencari pola dan informasi yang menarik dalam data terpilih dengan menggunakan teknik atau metode tertentu.

\section{METODOLOGI PENELITIAN}

\section{A. Analisa Sistem Aktual}

TokoEdeleweis adalah merupakan salah satu toko yang bergerak dibidang penjualan pakaian seragam Sekolah, Pramuka, ABRI, Satpam, Polisi, Hansip, yang terdapat di Kelurahaan Sukamerindu Kota Bengkulu, saat ini Toko Edeleweis belum menerapkan suatu strategi marketing dalam menajemen persedian barang di Toko Tersebut. Untuk Membantu efektifitas dalam pengolahaan persedian barang. Dibutukan suatu sistem yang dapat membantu memberikan informasi tantang barang - barang mana saja yang harus dilanjutkan untuk persedian barang . dengan melihat dari hasil transaksi penjualan yang terjadi selama ini.lam melakukan penelitian ini, peneliti menggunakan metode pengembangan sistem. Disini peneliti mengembangkan bagaimana cara kerja implementasi metode algoritma k-means clustering pada toko eidelweis yang bersifat manual menjadi sistem penginputan data menggunakan Aplikasi Visual Basic Net dengan database SQL.

B. Metode Perancangan Sistem

Sistem baru merupakan pengembangan sistem lama untuk mengatasi permasalahan yang terdapat pada sistem lama. Sistem baru yang dimaksud adalah dengan membuat aplikasi data mining dengan menerapkan Algoritma K-Means Clustering untuk menentukan penerapan implementasi pada Toko Eidelweis Kota Bengkulu.
C. Penerapan implementasi Algoritma K-Means Clustering Pada Toko Eidelweis

Perancangan Algoritma K-Means Clusterin Penerapan implementasi Pada Toko Eidelweis antara lain :

1. Menentukan nilai $\mathrm{k}$ sebagai jumlah dalam cluster yang ingin dibentuk.

2. Bangkitkan $\mathrm{k}$ centroid(titik pusat cluster) awal secara random

3. Hitung jarak setiap data ke masing-masing centroid

4. Setiap data memilih centroid yang terdekat.

5. Tentukan posisi centroid yang baru dengan cara menghitung nilai rata-rata dari data-data yang terletak pada centroid yang sama.

6. Kembali ke langkah-3 jika posisi centrroid baru dengan centroid yang lama tidak sama.

\section{Perhitungan Manual}

Data yang diperlakukan dalam penelitian ini diperoleh dari Toko Edeleweis yang berupa data penjualan.

Tabel.1 Sampel Data Penjualan Pada Toko Edeleweis

\begin{tabular}{|l|l|c|c|}
\hline No & $\begin{array}{c}\text { Nama } \\
\text { Barang }\end{array}$ & $\begin{array}{c}\text { Jumlah } \\
\text { Barang }\end{array}$ & $\begin{array}{c}\text { Jumlah } \\
\text { Terjual }\end{array}$ \\
\hline 1 & Sepatu PDH & 35 & 16 \\
\hline 2 & Bel Polisi & 36 & 25 \\
\hline 3 & Bel Security & 57 & 32 \\
\hline 4 & Mantel & 28 & 25 \\
\hline 5 & Celana & 37 & 24 \\
\hline 6 & Sepatu & 32 & 27 \\
\hline 7 & Monogram & 15 & 6 \\
\hline 8 & Bel Pol PP & 26 & 12 \\
\hline 9 & Baju Sapari & 18 & 9 \\
\hline 10 & Tempat HP & 28 & 12 \\
\hline 11 & Kaos & 25 & 11 \\
\hline 12 & ATM & 20 & 12 \\
\hline 13 & $\begin{array}{l}\text { Tukartamba } \\
\text { h Sepatu }\end{array}$ & 15 & 3 \\
\hline 14 & Bel Sepatu & 47 & 28 \\
\hline 15 & $\begin{array}{l}\text { Pangkat } \\
\text { PNS }\end{array}$ & 24 & 13 \\
\hline 16 & Bel Dishub & 18 & 7 \\
\hline 17 & $\begin{array}{l}\text { Celana } \\
\text { Panjang }\end{array}$ & 22 & 8 \\
\hline 18 & Lampu lalin & 20 & 7 \\
\hline & & & \\
\hline
\end{tabular}

Pada tahap ini akan dilakukan proses utama yaitu segmentasi atau pengelompokkan data Penjualan Barang yang diakses dari database, yaitu sebuah metode clustering algoritma K-Means. Dari banyak data penjualanbarang yang diperoleh pada toko eidelweis, Percobaan dilakukan dengan menggunakan parameter-parameter berikut : 
1. Jumlah Cluster : 2

2. Jumlah Data $: 18$

3. Jumlah Atribut : 2

Kemudian menentukan perhitungan pusat awal cluster atau centroid yang didapatkan secara random, untuk menentukan awal cluster maka dapat di asumsikan sebagai berikut :

Pusat Cluster $1: 28,25$

Pusat Cluster 2 : 20,9

Setelah itu ditentukan titik awal pusat cluster pada masing-masing cluster, dimana cluster yang digunakan sebanyak 2 cluster yaitu dari 10 data yang di jadikan Sampel telah dipilih pusat awal cluster yaitu, $(\mathrm{C} 1,28,25)$ dan $(\mathrm{C} 2,20,9)$. Kemudian dilakukan perhitungan jarak dari sisa Sampel data dengan pusat cluster yang dicontokan dengan $\mathrm{M}(\mathrm{a}, \mathrm{b})$ karena $\mathrm{a}$, merupakan jumlah stok barang, dan b. Merupakan jumlah barang yang terjual seperti pada tabel 3.2 dibahwa ini :

Tabel.2 Inisialisasi Data Atribut

\begin{tabular}{|c|c|c|}
\hline No & A & B \\
\hline 1 & M1,35 & 16 \\
\hline 2 & M2,36 & 25 \\
\hline 3 & $\mathrm{M} 3,57$ & 32 \\
\hline 4 & M4,28 & 25 \\
\hline 5 & M5,37 & 24 \\
\hline 6 & M6,32 & 27 \\
\hline 7 & $\mathrm{M} 7,15$ & 6 \\
\hline 8 & $\mathrm{M} 8,26$ & 12 \\
\hline 9 & $\mathrm{M} 9,18$ & 9 \\
\hline 10 & $\mathrm{M} 10,28$ & 12 \\
\hline 11 & $\mathrm{M} 11,25$ & 11 \\
\hline 12 & $\mathrm{M} 12,20$ & 12 \\
\hline 13 & $\mathrm{M} 13,15$ & 3 \\
\hline 14 & $\mathrm{M} 14,47$ & 28 \\
\hline 15 & $\mathrm{M} 15,24$ & 13 \\
\hline 16 & $\mathrm{M} 16,18$ & 7 \\
\hline 17 & $\mathrm{M} 17,22$ & 8 \\
\hline 18 & $\mathrm{M} 18,20$ & 7 \\
\hline
\end{tabular}

a. Diagram Konteks

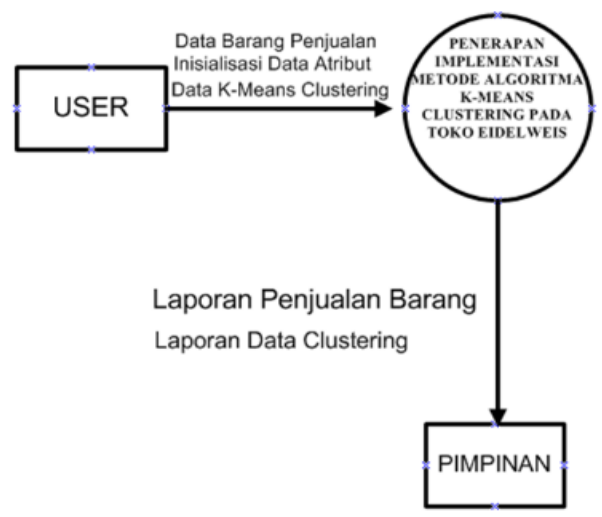

Gambar1 Diagram Konteks b. Tampilan ERD

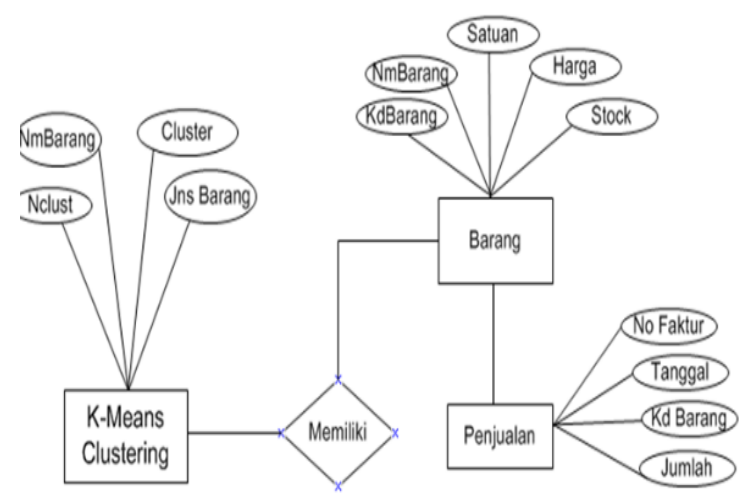

Gambar 2. Entity Relationship Diagram

\section{HASIL DAN PEMBAHASAN}

A. Hasil

Aplikasi implementasi metode algoritma Kmeans Clustering pada Toko Eidelweis dibuat dengan Bahasa pemrograman Visual Basic Net dengan database SQL Server sebagai media penyimpanan hasil pengolahan data. Pada bab ini, akan dijelaskan hasil dan pembahasan rancangan perangkat lunak pada toko eidelweis pada aplikasi ini nanti terdapat menu login, menu input, menu output dan menu laporan, menu utama. Pada menu utama terdapat sistem yang menghubungkan ke menu - menu selanjutnya dalam proses untuk melihat laporan tentang penjualan pada took Eideleweis

\section{Tampilan Menu Utama}

Menu utama merupakan form yang akan muncul ketika kita berhasil login pada sistem Aplikasi implementasi metode algoritma K-means Clustering pada Toko Eidelweis. Dimana form menu utama terdiri dari menu input data, output data, dan menu keluar. Adapun form menu utama

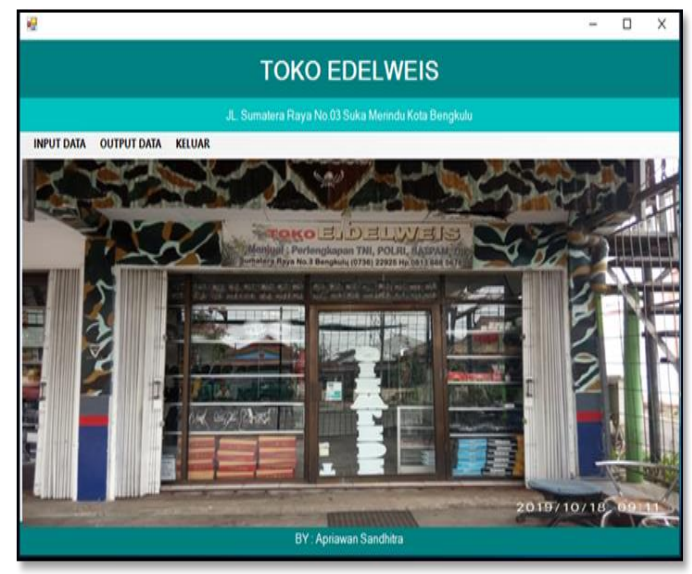

Gambar 3 Tampilan Menu Utama 


\section{Tampilan Menu Input Data}

Pada file menu input data terdapat beberapa sub menu yaitu sub menu Data barang, Data Penjualan, Data K-Means Clustering. Adapun tampilan menu.

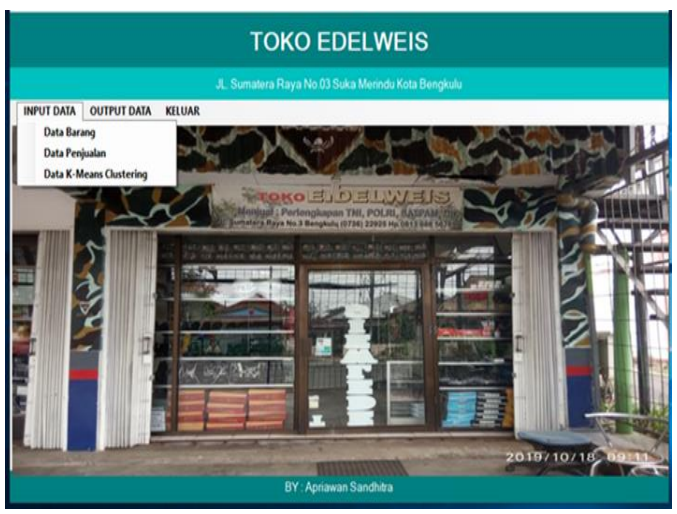

Gambar 4 Tampilan Menu Input Data

\section{Tampilan input data barang}

Tampilan input data barang adalah menu untuk menginput data barang yang berisikan field kode barang,nama barang yang merupakan field kunci (primay key ) yang digunakan untuk memanggil field - field yang telah dientrikan dan tersimpan dalam database. Adapun tampilan Input Data Barang.

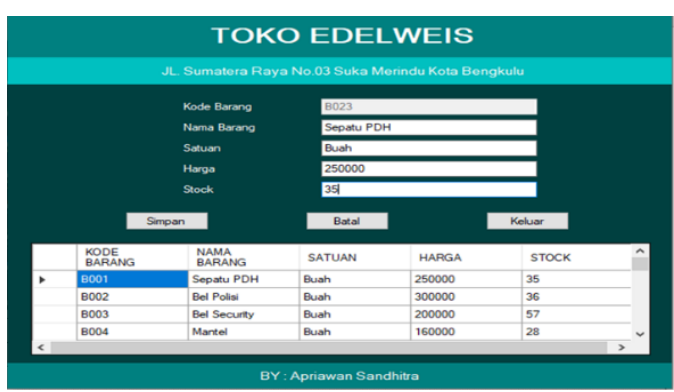

Gambar 5 Tampilan input data barang.

4. Tampilan Input Data Penjualan

Tampilan input data penjualan menampilkan data barang yang sudah di input dari awal dan sudah melalui proses transaksi, sehingga menghasilkan data barang yang ada pada toko Eidelweis, dan mempermudah admin melakukan pemantauan data barang, dan bisa melakukan penambahan atau pembelian barang untuk menambah stok barang. Adapun tampilan Input Data Penjualan

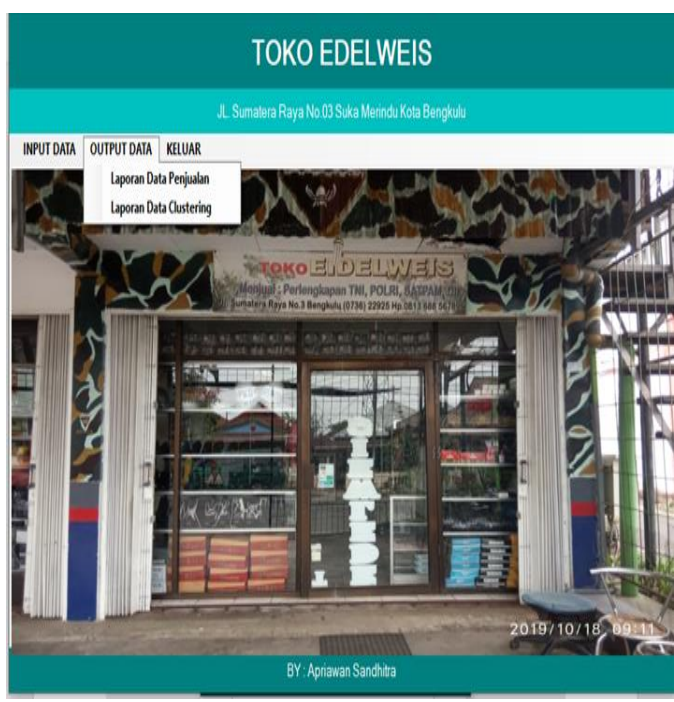

Gambar 6 Tampilan Input Data Penjualan

5. Tampilan Input Data K-Means Clustering

Tampilan input data K-Means Clustering merupakan proses dimana akan dilakukan penginputan data barang yang telah di input tadi, kemudian melakukan proses K-Means Clustering untuk mendapatkan nilai cluster. Adapun tampilan input data K-Means

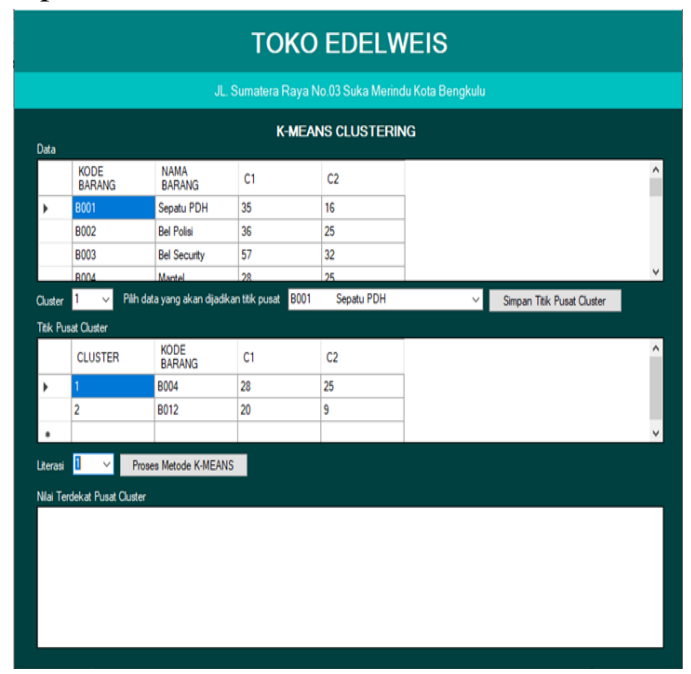

Gambar 7 Tampilan Input Data K-Means Clustering

6. Tampilan Output Data

Pada file menu output data terdapat beberapa sub menu yaitu sub menu Laporan Data Penjualan, Laporan Data Clustering,. Adapun tampilan menu output data. 


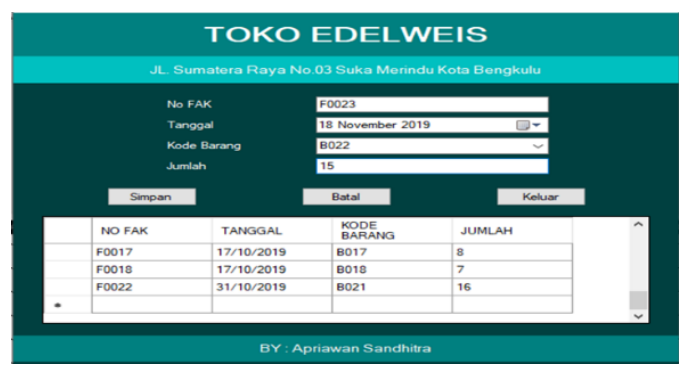

Gambar 8 Tampilan Output Data

7. Tampilan Output Laporan Data Penjualan

Tampilan output laporan data penjualan menampilkan data barang yang sudah di input dari awal dan sudah melalui proses transaksi, sehingga menghasilkan data barang yang ada pada Toko Eideleweis sesuai dengan stok barang yang tersedia pada toko Eidelweis dan mempermudah admin melakukan pemantauan data barang. Adapun tampilan laporan data barang.

\begin{tabular}{|c|c|c|c|c|c|}
\hline \multicolumn{6}{|c|}{$\begin{array}{c}\text { TOKO EDELWEIS } \\
\text { sL. Sumatera Raya No.03 Suka Merindu Kota Bengkulu }\end{array}$} \\
\hline \multicolumn{6}{|c|}{ Laporan Data Barang } \\
\hline$\underline{\text { NO}}$ & KODE BARANG & NAMA BARANG & SATUAN & HARGA & $\underline{\text { STOCK }}$ \\
\hline 1 & Bo01 & Sepatu PDH & Buah & 250.000 & 35 \\
\hline 2 & 8002 & Bel Polisi & Buah & 300.000 & 36 \\
\hline 3 & 8003 & Bel Secunity & Buah & 200.000 & 57 \\
\hline 4 & 8004 & Mantel & Buah & 160.000 & 28 \\
\hline 5 & 8005 & Celana & Buah & 100.000 & 37 \\
\hline 6 & 8006 & Sepatu & Buah & 200.000 & 32 \\
\hline 7 & 8007 & Monogram & Buah & 300.000 & 15 \\
\hline 8 & B008 & Bel Pol Pp & Buah & 200.000 & 26 \\
\hline 9 & 8009 & Baju Sapani & Buah & 300.000 & 18 \\
\hline 10 & B010 & Tempat HP & Buah & 140.000 & 28 \\
\hline 11 & B011 & Kaos & Buah & 100.000 & 25 \\
\hline & & & & & \\
\hline
\end{tabular}

Gambar 8 Tampilan Output Laporan Data Penjualan

8. Laporan Hasil Cluster

Laporan Hasil Cluster merupakan menu input untuk menampilkan hasil dari nilai cluster. Adapun tampilan hasil cluster

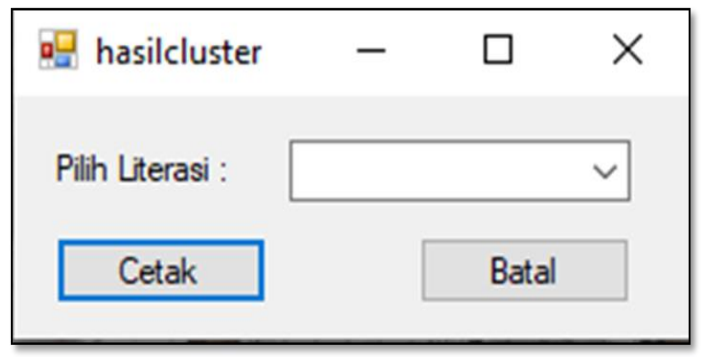

Gambar 10 Laporan Hasil Cluster
9. Laporan Data Hasil Clustering

Laporan Data Hasil Clustering adalah untuk menampilkan data barang hasil clustering yang terdapat pada toko Eideleweis. Adapun tampilan laporan data hasil clustering

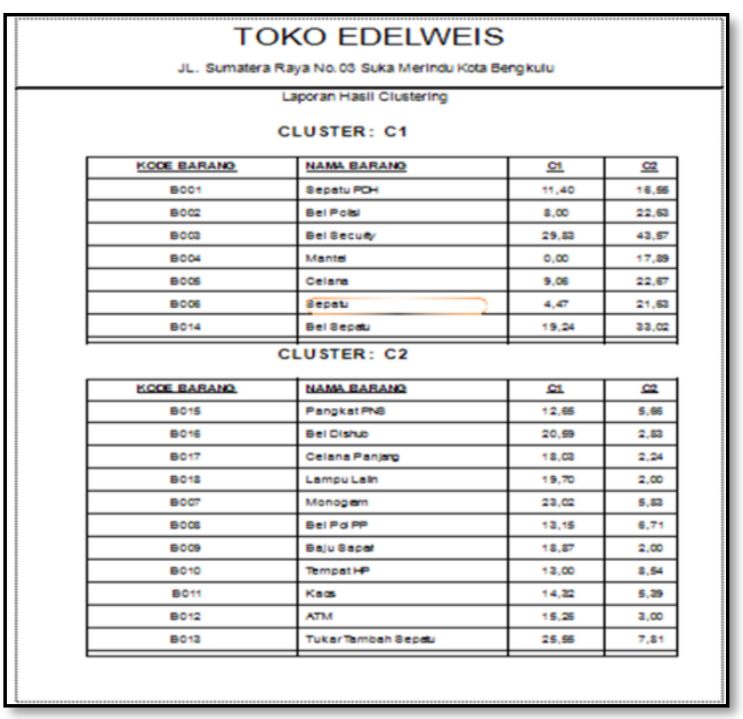

Gambar 11. Laporan Data Hasil Clustering

\section{IV.PENUTUP}

A. Kesimpulan

Berdasarkan hasil dari pembahasan tersebut, maka dapat disimpulkan bahwa :

1. Dalam implementasi metode algoritma Kmeans Clustering pada Toko Eidelweis menu login, menu input, menu output dan menu laporan, menu utama. Pada menu utama terdapat sistem yang menghubungkan ke menumenu selanjutnya dalam proses untuk melihat laporan tentang penjualan pada took Eideleweis mudah untuk dioperasiaka

2. Dalam proses implementasi metode algoritma K-means Clustering pada Toko Eidelweis telah diterapkan metode K-means Clustering,

3. Aplikasi implementasi metode algoritma Kmeans Clustering pada Toko Eidelweis dibuat dengan Bahasa pemrograman Visual Basic Net dengan database SQL Server sebagai media penyimpanan hasil pengolahan data

\section{DAFTAR PUSTAKA}

[1] M. N. M. Ediyanto, N. Satyahadewi, "Pengklasifikasian Karakteristik Dengan Metode K-Means Cluster Analysis". BIMASTER, Vol. 2 No.2. 2013.

[2] J. O. Ong. "Implementasi Algoritma K-Means Clustering untuk Menentukan Strategi Marketing President University". Jurnal Ilmiah Teknik Industri. Vol. 12 No. 1. 2013. 
[3] T. Gomasathit. "Cloud Coverage Identification Using Satellite Data and K-mean Clustering Algorithm". Journal of Global Research in Computer Science, Vol. 4. No. 7. 33-37. 2013.

[4] Luthfi, K. D. Algoritma Data Mining. Yogyakarta: Andi Offset. 2012. 